\title{
Representation Of Social Education Value Of Transgender Character In The Novel Of Calabai By Pepi Al-Bayqunie As Stimulus Of Character Building In Prose Appreciation Learning In Stkip Ponorogo
}

\author{
Krisna Aji Kusuma ${ }^{*}$, Herman J. Waluyo ${ }^{2}$, Nugraheni Eko Wardani ${ }^{3}$ \\ 1,2,3 Universitas Sebelas Maret
}

\section{A R T I C L E I N F 0}

Article history:

Received 26 January

2018

Received in revised

form

15 February 2018

Accepted 12 March

2018

Available online 20

May 2018

Keywords:

character building,

representation, social

education value

\begin{abstract}
A B S T R A C T
This research is a qualitative descriptive research that aimed to understand the life of the transgender figure in the novel of Calabai, analyzing the values of social education reflected through the example of calabai attitude, and analyzing the integration of social education values of calabai figures as a stimulus to build character in learning of prose appreciation in STKIP PGRI Ponorogo. The source of data used in this research is Calabai novel document by Pepi Al-Bayqunie, while the data collected in the form of the result of the study note of the novel. Data collecting technique uses non-interactive technique by doing intensive reading on the novel and do recording actively by content analyzing method. Validity of this research uses data triangulation technique and method of triangulation. Data analysis techniques using interactive analysis model, which is data reduction, presentation, and conclusion. The results of this research show that the sensitivity and the concern of transgender characters in the novel of Calabai to fellows is a representative value of social education model to the younger generation. The value of social education reflected through the transgender figure in the novel of Calabai includes the social attitude of caring family, caring friend, and caring for the community. Social care is manifested in the form of obedience, patience, sacrifice, sincerity, religious, sympathy and empathy, gratitude, and compassion. The values of social education represented by transgender figures in the novel Calabai can be used as a stimulus to build character in prose appreciation learning in STKIP PGRI Ponorogo.
\end{abstract}

\section{Introduction}

The transgender phenomenon becomes a public polemic. Their presence invites positive and negative views and discussed to become trending topic in some social media. News about Lucinta Luna appearing in early 2017 is a portrait of reality existence of transgender issues in Indonesia. Lucinta Luna figure exists because of her rejection upon transgender identity pinned to her. The appearance of Lucinta Luna draggs back the transgender's predecessor, from Dena Rachman to Dorce Gamalama who are regarded as transgender pioneer. Of course the existence of transgender raises public opinion that their decision was incorrect and against the nature. Supporting the opinion, Judah in his research on transgender concludes that transgender representation in news has transphobic elements of fear of transgender, containing prejudices and stereotypes and displaying hate against transgender (2013:37).

Understanding about transgender, it is a person who has a gender identity or gender expression that is different from the gender stated at birth (Setiawan, 2017:129). Firliani Purwanti gives an explanation of transgender as someone who wears gender attributes differently from the conception of gender socially constructed by the society (Judah, 2013:38). Rizter in the research of Gunawan Saleh 
explained that transgender is the inequality of gender identity given to the people by their sex identity (2017:152). Further detail is explained by his research that in Barmawi the term transgender is addressed to someone who cannot show his sexual orientation, specifically as a transgender male is a normal man, who has normal sex organ, but psychologically feels himself as female. As a result of daily behavior often seems stiff, physically male, but the way how to walk, talk and dress up are like women.In the same way it can be said these men were trapped in the wrong body (2016:373). Fajarina at her studies of the formation of self ideal adds explanation that transgender issues dealing with perception of how a transgender should behave in accordance with a desire to be a woman who behaves femininely by changing his daily activity and behaves as if he were a woman (2017:100).

Regardless of pros and cons about the transgender among the people, the thing to be accepted is the fact that they do exist. They are also human beings as social creatures that live in the community. Abrams explained that the social environment of society and culture contributes to the formation of transgender identity (2009:111). Fajarina adds that how parent keep their child and support from fellow masters affect the formation of self-ideal as a transgender (2017:100). Transgender behavior can not instantly be blamed since it concerns with one's natural desire and instinct. It does not mean that a transgender is always oriented to negative things and we deserve to give them a label as a deviant human being. If you can see from another point of view, it is possible to find a positive side of a transgender. Transgender person has more concerns and sensitivity to others and people around him.

Living in a complex social order society, representing everything happens in it becomes a valuable learning for each individual. A unique person in transgender can be used as a stimulus for a learning of all aspects, and one of the most important aspects of learning is education. The notion of education is not only to equip human being with knowledge, but also to expand their orientation to get a good personality and human character.

Slightly discussing about education, according to Sisdiknas Law Number 20/2003, Article 3: National education serves to develop the ability and to form the character and civilization of a dignified nation, in order to educate the life of the nation. Based on the article in the National Education System above, it is clear that the government is very concerned with the development of the character of the nation's generation. It is undeniable that the sustainability of the milestone of the founding of a nation depends on the development of the character of the next generation of the nation itself. Character education is the nation's main agenda in anticipating the worries of moral eroded and a cure for the degradation of the nation's character. Therefore, the role of education is very important to create the nation's generation, not only being qualified in the cognitive and psychomotoric realms, but also able to express the attitude which reflects the dignified generation. Due to the paradigm, it is very appropriate for the government to step through the Ministry of Education and Culture (Kemendikbud), striving to apply character education from the level of Early Childhood Education (Pendidikan Anak Usia Dini), secondary school (Sekolah Menengah Atas / Madrasah A'liah), to universities (Perguruan Tinggi).

Specifically to the level of university, character education is not only taught directly (direct teaching) in courses related to moral education, it can also be integrated (indirect teaching) with other courses. One of them is prose appreciation course. The main object of the prose appreciation course is literature. Novel as one of literary works has a useful content, elevating the degree of humanity and teaching the values of noble education. It means that literature can be a means of awareness and education for the readers. In particular, literature becomes an effective medium to internalize the educational values to the students.

As a medium of internalization of educational value, Saryono (in Wibowo, 2013:131) mentions that there are 4 literary genres that are able to optimize the national character building especially to the students. One of the literary genres is the one that contains ethical and moral values. Described by Wibowo, that the genre of ethical and moral literature refers to the human experience in attitude and action, exercising right and wrong, and how to fulfill human obligations and responsibilities. (2013:133).

One novel containing ethical and moral values is a novel entitled Calabai. Pepi Al-Bayqunie as the author gives the title of Calabai because it tells the life of the main character whose personality is defferent from his real gender. Calabai is defined as someone who was born as a man but behaves like a woman. A calabai can be assumed to be the same as a transgender. The novel of Calabai tells about a male-born figure with fvery solid female characteristic. The struggle of the soul trapped in a wrong body that is not suitable with its nature, feminine soul and behavior in the masculine physic. The main character named Saidi and a friend, Vienna, as well as the bissu, are all calabai whose life are attractively portrayed by Pepi Al-Bayqunie. Telling about the life of the calabai, the author does not forget to deliver moral message and educational value. The same opinion was written by Purwaningsih in his research that the power of the 
novel of Calabai is based on the history of the ancestral traditions of the Bugis society. So the issue of transgender is not only considered as a sexual issue but there are values of nobility (2017:183). The prominent value of nobility and should be taken as a lesson from the life of calabai characters in the novel is the value of social education exemplified.

The value of social education is defined as the value that people gain in their interactions with other human beings in society. The value is related to the formation and maintenance of behavior for the benefit and common welfare (Purwaningtyastuti, 2014:8). In Calabai novel, the value of social education is represented through the description of the lives of the characters who, even though the public rejects their presence as calabai, yet they do many things that are beneficial to society. All social activities of calabai figures can be regarded as a proof process to obtain self-esteem and responsibility for the life choices they have determined it as a consequence of the soul of a woman trapped in a man's body. Based on this understanding, it can be assumed that the identity of calabai or transgender is not entirely negative, but there are also positive things that can still be emulate.

The term of calabai is still strange to the ears of the public, either public in general or especially in the field of education. In the educational field, in STKIP PGRI Ponorogo is also conducted a research on students about the term of calabai. Not many know the real meaning of calabai and they are more familiar with the term of transgender. STKIP PGRI Ponorogo is the only college in Ponorogo that focuses on the world of education. One of the subject oriented to the novel as the material of this study is the prose appreciation course. Based on the interviews with lecturers, the problem of prose appreciation learning in STKIP PGRI Ponorogo is students' lack in reading on literary works, especially novels. This is due to their low interest and motivation to read. Lecturers have attempted to overcome these learning barriers by mode changing strategy. For example, they show a movie based on a novel. This strategy however was less effective in motivating students to get interested in literature works. The chosing of Calabai novel which its theme is the story of transgender life becomes a solution to the problem of the prose appreciation. It becomes interesting, since the transgender phenomenon raised into a novel story will present a new atmosphere in prose appreciation learning and change the students' mind so they will not look at the transgender figure from a single point of view. Their concern on social values will become noble education value in life.

As the only university that focuses on the world of education, STKIP PGRI Ponorogo has a vision to become an excellent university in the development of science education, teacher profession, science, and technology in the field of ethical language and art and character. In accordance with the vision to make ethical and characteristic human, Calabai novel is suitable to use as a teaching material in the prose appreciation course, especially related to novel extrinsic element analysis, discovering social education value exemplified by its characters. In accordance with the standard of competence in the syllabus of prose appreciation course that understands the concept of appreciating prose, getting acquainted, loving, and finally appreciating, applied in odd semester at the basic competence (Kompetensi Dasar) of prose appreciation. Learning steps to appreciate the prose begins with the activities of learners to read and then analyze the values of social education to emulate and apply it in daily life.

This study aims are to understand the life of a transgender figure in the novel of Calabai, analyze the values of education reflected through social attitudes in the form of sensitivity and concern for others and the environment, and analyze the integration of the social values of calabai characters as a stimulus to build character in learning of prose appreciation course in STKIP PGRI Ponorogo. The study of the theory used in this study related to the nature of transgender, the nature of prose appreciation learning, and calabai as an example of the representation of the value of social education..

\section{Method}

The research conducted at SMP Negeri 11 Manokwari. The population in this research is the The method used in this research is descriptive qualitative method. The strategy used is phenomenology, which focuses on the matter of consciousness. The main concept in phenomenology is meaning, an important thing that arises from the experience of human consciousness. The source of data used in this research is the novel of Calabai by Pepi Al-Bayqunie published by Javanica in 2016. While the data collected in the form of the results is the record document of Calabai novel by Peppi Al-Bayqunie. Data collection techniques use noninteraktif technique by doing intensive reading on the novel and recording actively by content analysis method. Validity of the data to test the validity of this study uses data triangulation techniques and triangulation methods. Data analysis technique uses interactive analysis model, namely data reduction, data presentation, and conclusion. 


\section{Discussion}

A conflict in the novel is inseparable from the interaction between the characters, either the family or society as a social member, as in Calabai novel by Pepi Al-Bayqunie. The novel tells the life of the main character who is shackled in a body that is not in accordance with his soul. All acceptance and rejection is experienced by the character, thus deciding to seek his own way of life according to his soul instinct. The journey to escape from the self isolation due to the rejection of family and society that ultimately make the figure get difficulty to socialize well. However, Saidi as the main character in the novel has a high social care to prove that a calabai is a social member who has a conscience and concern for others. Not only focus on the main character, but there are also some supporting characters who have the same identity, namely calabai.

The value of social education is the social value related to human relationships in society so it makes people aware the importance of life together, the group in the bonds of kinship among individuals. Social values include the necessities of living together, such as affection, trust, recognition, and appreciation. Social value in question is a concern for others and the environment. Social values are also related to the rules or norms in a certain place; beside the care to understand and make family happy is also a reflection of social attitudes. Awareness of a child's obligation to parents is well understood by Saidi. The inner torture he got just to obey his father's wishes. He gets rough work and hard instruction every day. He just wants to keep his father not getting angry. He feel his father's anger is more painful than the hard work he does. Physical fatigue is less pronounced than the deep tiredness of the heart. This condition leads Saidi to always obey his father's wishes, to make his father happy and proud naturally as parents. It is a picture of social caring attitude toward the family in the form of obedience to the parents (C: 13).

Social concern is not only about the problem of the attitude or things should be done by someone, but also how to maintain the feeling of the parents. How hard our parents teach us, we must understand that it is a mandatory for a child to obey what the parents command as long as the order is true and good. A social caring attitude that describes a parenting attitude. The weak of physical condition is not shown by Saidi to his father. He prefers delaying to release his hunger to violating his father's orders. Any advice expressed by his father should be a wise advice to Saidi, but it is contrary to the fact. The answer that Saidi represents through dutiful behavior to Father is solely to calm and dampen father's anger over the attitude of the feminine-behaved boy (C: 19-20). Saidi did not decide to leave the living room before his father finished speaking. The two descriptions of the events above show Saidi's social attitude toward parents in the form of patience to put parents' desires first before personal desires (C: 21).

A sacrifice must be done by a child for the salvation of the parents. Like a wheel, life goes through a cycle. When we were a baby, the parents are obliged to take care of us. When the child has been adult and the parents have been very old, the child is obliged to care for the parents. The reciprocity is certainly the law of nature. Saidi's worries when he was in Segeri proved true. His mother is sick and no one is able to get her to the hospital due to the cost and for Saidi's father, there is no word of hospital in his life's dictionary. However, it is not Saidi's mind. Without a long thought he asked his brother to find a vehicle for his mother and immediately took her to the hospital, because he saw the physical condition of his mother who was very weak. The high cost of the hospital did not become a burden for Saidi because what he prioritized was his mother's safety. The incident is a picture of the value of family social education in the form of sacrificing by the main character Saidi (C: 320).

Sacrificing not to demand something that is in fact the right of a child who has made the sacrifice shown by the character Saidi to his father, although from childhood Saidi never got the nice attitude and attention from his parents. There is an event that illustrates how Saidi still sincerely accepts all the attitudes shown by his father, the man who always rejected him, despite what he had done to save his mother's life. It is a shame for father to thank to the calabai boy and Saidi really understands his father's characteristic. Here are events that imply a message that there is no parental reply to the child. It is the duty and responsibility of the child to take care for and protect the elderly at old age, all of which should be done sincerely. A picture of the caring social attitude of the family in the form of sincerity to always keep and place the salvation of the parents above all (C: 322 ).

The happiness of parents in seeing the success of their children does not mean to make children forget to think of the parents' heaven. The needs and satisfaction of the world are very easy to fulfill, but the provision for heavenly happiness is not every human to be able to make it happen. Saidi's figure shows his concern for parents not only in financial terms, but also in spiritual terms. An event that illustrates how a child continues to give a very special award to parents. Saidi successfully sent his parents to go to 
Mecca. Something impossible for both parents to set foot in the holy land, but Saidi was able to make it happen. Although he is aware that he is Calabai and embraces a different belief from his parents, Saidi still upholds the religion that his parents believe. Although Saidi has a miserable past related to his father's rejection of his psychological problems he does not hold a grudge. He believes the success of life that he got is due to the prayers and blessings of his parents. It is appropriate that Saidi repay the hard work and sacrifice of his parents who have raised and educated him with something beautiful. This is anexemplary form of Saidi as a representation of social education concern for the family in the form of spiritual needs fulfillment (C: 346).

The value of social education is the relationship between human beings, which includes human relationships with others. Humans as social beings always need others, although basically in man there is the nature of the individual that always puts his own interests first. The self power to live independently is possessed by every human being as an individual, but a human being is also equipped with hearts and feelings that are sometimes unable to bear a deep inner burden. At that time, man will need another to ease his inner burden even by simply listening to his complaints. The life story of Grandma Sagena brings pity and awareness to Saidi. Once he feels to be the most miserable one in the world and it turns out to be wrong. There are still many humans who have a bitter experience in the world besides himself. Although Saidi only knew Grandma Sagena, yet a sense of empathy had appeared to Saidi for her. Although she is in her old age, Granny Sagena did not want to succumb to her difficult life. Grandma Sagena chose to keep fighting her hard life because she realized she was alone. As someone younger than Grandma Sagena, Saidi feels sympathy with the grandmother's determination in fighting for life. Saidi's sense of sympathy and empathy is a picture of the value of social education cares about friends. Although Saidi does not have relative relationship, he thinks Grandma Sagena is a friend whom he can share feelings each other (C: 64).

Social concerns are sometimes not merely present in one's consciousness, but appear spontaneously when they see others stricken. Social instinct to help others in distress. From the misfortune experienced by an old man, a sense of empathy appears in Saidi. Of course he also feels a fear because the people whom he wants to assist are people he does not know well, but pity has encouraged him to help the man in pain. Saidi swiftly treated the man's wound with his knowledge of the herbal remedies taught by his mother. It describes the social caring attitude that must be done by man as a living being in a social order of society (C: 71-72).

As a social being, a person should be able to put himself in a new environment, especially if the person is a guest. More over a guest in the house of the person who has provided him protection and safety of life. The morning routine performed by Saidi is a sincere thing he does for the man who has helped save his fate. Daeng Maddenring was the one who had brought Saidi into a man who had his place. Starting from the misfortune experienced by Daeng Maddenring who was saved by Saidi, in return Daihat Maddenring invites Saidi to stay in his house even Saidi was appointed as a child. Although he has saved the life of Daeng Maddenring, it does not necessarily Saidi feel to be a better human. Precisely with the kindness of the old man Saidi realizes that there are still people who are willing to accept and do not underestimate on his being calabai. This awareness demanded Saidi to give a reply to the goodness of Daeng Maddenring. The small routine done every morning by Saidi to serve everything that Daeng Maddenring needs is an example of the representation of the value of a caring social education friend which is packed in the form of repayment (C: 82).

The word mutual is an indication of the social life of society. Caring for others is not only present to one party, but will be followed by each party, especially when it comes to common needs. This is a humanist interaction that runs naturally. No matter how sturdy a person is in living a living tempest, at some point he will experience a weak point as a sign of human inability to bear the burden of the mind. In a fragile condition, a person needs the presence of others to strengthen. A cheerful characteristic of Wina is not a guarantee of the happiness of her inner vitality. Wina is still a human with limited space of patience. Wina was hurt by her ex-lover who left her, while she still loved him very much. She felt the spirit of life has gone. When it comes to the feelings, it is difficult for a person to be able to rise up to the normal and that is natural. This is where the role of friends is very big and Saidi took it. Saidi really understands that it is easier to shed complaints to friends than parents. Moreover, Wina is far away from her parents. As a friend, Saidi strives to provide support and strength for Wina to be able to forget her lover and dare to accept the fact that it is bitter (C: 244). Events that imply an example of a caring social attitude of a friend who is willing to listen to complaints about life experiences, whether fun or painful. A representation of the value of social education is described by two friends very neatly in the form of mutual support and strengthen framed with a loving sense of affection.

The value of education related to social attitudes is not limited to the notion of sensitivity, sympathy and empathy towards the closest people. Sacrifice to defend, save the community as a fellow and respect 
the surrounding environment is included in the representation of the value of social education. Wina is aware of her identity as a calabai to whom some people underestimate. The fact that does not make him resigned to the isolated conditions. Wina shows her independence with a sense of care for the surrounding community environment. Beauty salon that she opened to kill time and boredom was progressing. Because of her skill in hairdressing and makeup attracts many Segeri people to visit her salon. But she did not want to enjoy the success of the business alone. She wants to share the pleasure by taking some calabai in Segeri to join developing the salon. Wina's attitude has provided job for the other calaba is and opens up employment for them. The value of social education in the form of awareness of the community, which is represented through positive action, has put calabai in Segeri in more dignified position (C: 191).

A calabai is identical to physical grace, but it does not mean without physical strength. At the nature of a man born, it is reasonable masculine power remains inherent in the body. The sensitivity of the calabai conscience that exceeds the person with the appropriate identity becomes a great force behind his gentle physic. Unexpected events occurred after Saidi and the bissu finished performing the Manggirik dance. The stage where they dance suddenly burned. When everyone ran to save themselves, Puang Saidi took the opposite decision. She did it because she heard the cry of a child in the midst of a burning fire. Without thinking of self-salvation, he jumped in the flames to save the little boy. Saidi's sincere belief and sacrifice brings fruitful results through the smile of a rescued child. When other peeople only care about themselves a calabai shows her greatness to dare to sacrifice for society. Representation of the value of social education by the figure of calabai or more commonly known as transgender in the form of awareness through a sacrifice to the society environment (C: 293).

Calabai, more commonly known as transgender has a special characteristic. Masculine stature with feminine behavior. The main thing that needs to be underlined from the uniqueness of calabai behavior, that their sensitivity and concern for others become the representation of the value of social education that should be followed by the young generation. Some of the value of social education found in the transgender figure in the novel of Calabai include social attitudes caring family, caring friends, and caring community. Social care is manifested in the form of obedience, patience, devotion to parents, sacrifice, sincerity, religious, sympathy and empathy, gratitude, and compassion.

The values of social education of calabai figures can be used as a stimulus to build character in the course of appreciation of prose based on the Higher Education Curriculum and the values of social education can be linked to the cognitive and affective learning spheres. In the cognitive domain students are expected to be able to understand, analyze, evaluate, and interpret the material of transgender identity in some characters in the novel of Calabai in accordance with Basic Competence (KD) that is "to appreciate prose" with the subject of "appreciating the prose of the 2000s". While in the affective domain, after appreciating the novel of Calabai students are expected to explore and emulate the values of social education represented by transgender figures in the novel. The material on the values of social education in the novel will be well conveyed in the learning process if it is integrated into the syllabus and Rencana Pelaksanaan Pengajaran (Lesson Plan), because the two tools are the reference for the lecturer in planning the teaching materials that will be given to the students. In the current era, lecturers are required to choose and pack teaching materials that are more creative and innovative for the purpose of learning delivered to the student maximally. Like lifting the transgender phenomenon by looking at the positive side from the point of view of the value of social education exemplified through the characters in the novel of Calabai.

\section{Conclusions}

There are social education values represented by some transgender characters in the novel of Calabai, covering social attitude of caring family, caring friend, and caring society. Social care is manifested in the form of obedience, patience, devotion to parents, sacrifice, sincerity, religious, sympathy and empathy, gratitude, and compassion. The values of social education represented by transgender figures in the novel of Calabai can be used as a character building stimulus in prose appreciation learning in STKIP PGRI Ponorogo and its application adapts to Basic Competence in Lesson Plan used in learning activities.

Suggestions that researchers can ask related to prose appreciation learning include the following: For lecturers, must dare to occasionally get out of the positive zone to develop teaching materials by choosing teaching materials that lift social phenomenon of society that are considered deviant, but actually on the other side keep a lot of exemplary of life. Students must know and understand that not all objects that are considered negative for the community will give a negative effect. As an example is the 
existence of transgender. By looking from another perspective wee can find their positive side beneficial to society, such as the example of some of the characters in the novel of Calabai.

\section{References}

Abrams, M. H. 2009. A Glossary of Literary Terms: Cetakan kedua. Canada: Wadsworth Cengage Learning.

ALl-Bayqunie, Pepi. 2016. Calabai: Perempuan dalam Tubuh Lelaki. Tangerang Selatan: Javanica.

Asih, Putu Wusantri Widya dkk. 2017. Nilai-nilai Kepahlawanan Tokoh I Gusti Ketut Jelantik dalam Perang Jagaraga (1846-1849) Sebagai Sumber Penanaman Karakter dalam Pembelajaran IPS di SMP Laboratorium Undikhsa Singaraja. Jurnal Jere, 1(4), pp. 264-268.

Barmawi\&Silmi, Miftahus. 2016. Identifikasi Penyebab Transgender Pada Waria di Banda Aceh. Jurnal Psikoislamedia. Vol. 1 (2), 372-384.

Fajarina, Yossy Ayu, Judha Mohamad, Murdhiono, Wahyu Rochdiat. 2017. Studi Tentang Pembentukan Ideal Diri Transgender di Daerah Yogyakarta. Jurnal Keperawatan Respati Yogyakarta. Vol. 4 (1), 100-105.

Gibtiah. 2014. Studi Perbandingan tentang Khunsa dengan Transseksual dan Transgender (Telaah Pemikiran Ulama' Klasik Dan Ulama' Modern). Jurnal Intizar. Vol. 20 (2), 349-362.

Kasnadi \& Sutejo. 2010. Apresiasi Prosa: Mencari Nilai, Memahami Fiksi. Yogyakarta: Pustaka Felicha.

Nurgiyantoro, Burhan. 2013. Teori Pengkajian Fiksi: Cetakan kesepuluh. Yogyakarta: Gajah Mada University Press.

Purwaningsih. 2017. Transgender Dalam Novel Calabai Karya Pepi Al-Bayqunie: Kajian Identitas. Jurnal Aksara. Vol. 29 (2), 183-196.

Purwaningtyas, Ratna; Waluyo, Herman J; Tarjana, Sri Samiati; Winarti, Retno. 2014. Nilai Pendidikan dan Kesetaraan Gender dalam Novel. Surakarta: UPT. Penerbitan dan Percetakan UNS.

Saleh, Gunawan\&Arif, Muhammad. 2017. Rekayasa Sosial Dalam Fenomena Save LGBT. Jurnal Komnukasi Global. Vol. 6 (2), 148-163.

Setiawan, Wawan\&Sukmadewi, Yudhitiya Dyah. 2017. “Peran Pancasila Pada Era Globalisasi” Kajian Terhadap Pancasila dan Fenomna LGBT (Lesbian, Gay, Bisexual, Transgender) di Indonesia. Jurnal Dinamika Sosial Budaya. Vol. 19 (1), 126-147.

Sugiyono. 2015. Metode Penelitian Pendidikan Pendekatan Kuantitatif, Kualitatif, dan R\&D. Bandung: Alfabeta.

Universitas Sebelas Maret. 2016. Pedoman Tesis dan Disertasi. Surakarta: Penerbitan dan Percetakan UNS (UNS Press).

Waluyo, Herman J. 2011. Pengkajian dan Apresiasi Prosa Fiksi. Surakarta: UNS Press.

Wibowo, Agus. 2013. Pendidikan Karakter Berbasis Sastra: Internalisasi Nilai-nilai Karakter Melalui Pengajaran Sastra. Yogyakarta: Pustaka Pelajar.

Yudah, Anindita Ayu Pradipta. 2013. Representasi Transgender dan Transeksual dalam Pemberitaan di Media Massa: Sebuah Tinjauan Analisis Wacana Kritis. Jurnal Kriminologi Indonesia. Vol. 9 (1), 3749. 